Citation: Fulong Wu (2019) Land financialisation and the financing of urban development in China. Land Use Policy (in press).

\title{
Land financialisation and the financing of urban development in China
}

Fulong $\mathrm{Wu}$

Bartlett School of Planning, University College London, 14 Upper Woburn Place, London, WC1H 0NN. (fulong.wu@ucl.ac.uk)

Acknowledgement: I would like to acknowledge the funding support from UK Economic and Social Research Council (ESRC) on the project entitled "The financialisation of urban development and associated financial risks in China" (ES/P003435/1). I also thank research assistance from Yi Feng.

\begin{abstract}
There is a growing body of literature on China's land reform, land system and land-centred urbanisation. While the contribution of land proceeds to Chinese local public finance and infrastructure investment has been widely acknowledged, few studies examine land through the perspective of financialisation, namely how land development uses financial instruments to generate development finance. The process of land-driven financialisation in China has not been well understood. This paper examines the land mortgage, which has accelerated since 2008 , and subsequent waves of financialisation through local government financial vehicles (LGFVs) and Chengtou Bonds (urban construction and investment bonds). We highlight that the adoption of a fiscal stimulus package triggered land financialisation, which started as a development strategy for crisis management in China.
\end{abstract}

Key words: financialisation, land mortgage, local government financial vehicles, China

\section{Introduction}

China has experienced large-scale land development over the last four decades. Investment in land has fuelled economic growth and urbanisation, known as investment-driven or landbased urbanisation. There is a proliferating literature on land development in China (Lin \& Ho, 2005; Liu et al., 2018; Xu \& Yeh, 2009; Xu, Yeh, \& Wu, 2009; Yeh \& Wu, 1996), in particular the contribution of land revenue to public finance (Hu and Qian 2017; Huang \& Chan, 2018; Lin, 2014; Lin \& Yi, 2011; Shu et al 2018; Su \& Tao, 2017; Tao, Su, Liu, \& Cao, 2010; Tian, 2015; Wong, 2013; Ye \& Wu, 2014; Wu et al., 2015). This is known as the landbased fiscal revenue, or tudi chaizhen in Chinese, which in essence describes a condition of 
public finance. However, how land is used to create and deploy financial instruments to finance urban development is understudied.

Recent studies show the role of quasi-financial institutions such as local financing platforms, development corporations (Li \& Chiu, 2018), or broadly local government financial vehicles (LGFVs) are involved (Fan, 2016; Huang \& Chan, 2018; Huang \& Du, 2018; Wu, 2010). However, the overall picture of land-driven financialisation is not very clear. In this regard, few studies have specifically examined land from the perspective of financialisation (e.g. Aalbers 2016a, Theurillat, Vera-Büchel, \& Crevoisier, 2016; Weber, 2010).

The term financialisation is defined with reference to 'financialized capitalism' as 'a pattern of accumulation in which profit making occurs increasingly through financial channels rather than through trade and commodity production' (Krippner, 2005). In urban and housing studies, Aalbers (2016a, p. 3) provides a comprehensive definition as 'the increasing dominance of financial actors, markets, practices, and measurements, and narratives, at various scales, resulting in a structural transformation of economies, firms (including financial institutions), state and households'.

In this paper, we operationalise the definition of land financialisation as a tendency to use land as a financial asset to create financial capital to fund urban development projects. This is different from widely studied tudi chaizhen, which is sometimes translated in Chinarelated studies as 'land finance' as a contribution of land to public finance. Instead, this paper uses the perspective of financialisation to examine how land development in China uses financial instruments to generate development finance. Specifically, we investigate the waves of land financialisation from land mortgage, LGFVs, to Chengtou bonds. We argue that the adoption of a fiscal stimulus package triggered land financialisation, which started as a development strategy for crisis management in China but at the same time it creates a huge financial risk. For policy users, the paper reveals the original of financial risks in association with land. For researchers, the scope of land financialisation fills the gap of knowledge on the operation and mechanisms that use land to generate financial capital. This paper will therefore focus on financial operations and instruments rather than the fiscal contribution of land. We mainly focus on the local government practices because not only the local government plays a significant role in land development (Xu and Yeh, 2009; Xu et al 2009) and financialisation but also main developers are state-owned enterprises. LGFVs act as the primary and major developers in China's land market (Huang and Chan, 2018; Li and Chiu, 2018; Theurillat, 2017; Shen \& Wu, 2017). Although private sector developers use a variety of financial practices, some have been created but soon forbidden by the tightening of financial regulation. This paper will examine some of these practices too.

The remainder of the paper is structured as follows. First, the literature on financialisation and land is reviewed. Existing studies on China's land-based public finance are critically 
discussed with regard to financial operations. Second, the analytical framework is introduced to conceptualise the waves of land financialisation. Third, the waves of land financialisation are explained in detail through an historical account. The next three sections examine, respectively, the specific waves of financialisation, namely, land mortgage, LGFVs, and Chengtou Bonds. Finally, with a comparison with other contexts, this paper concludes that land financialisation is a strategy deployed by the state, in contrast to finance sectorinitiated financialisation.

\section{Literature review}

\subsection{A critical review of land-based finance in China}

Because land-centred urbanisation has made significant contributions to local public finance, current studies mainly focus on fiscal conditions which are dependent upon land income, hence 'land-based finance' (Huang \& Chan, 2018; Lin, 2014; Tao et al., 2010; Wu et al., 2015). For example, fiscal decentralisation and official promotion are the main reasons (Tao et al 2010; Tian 2015; Wong, 2013; Wu et al. 2015).

Su and Tao (2017) explained the mechanism of 'industrial linkage and spillover', in which the local government uses the land revenue from commercial and residential land to subsidize industrial land. They argue that local government tried to maximize land revenue, because industrial development led to the agglomeration of population which exerted greater demand for residential and commercial land. The changing behaviour in land development is due to local fiscal shortages, and 'the land regime provided the final institutional link that enabled local officials to leverage urban infrastructure and real estate for industrial expansion' (p. 230). On the other hand, while they argue that the strong drive of local government towards building industrial parks is due to 'fiscal reform and revenue imperative', their observation could be interpreted in a different way. The development of industrial parks could be not the means but rather the end - for GDP growth, or a GDP tournament target, as described by Li and Zhou (2005), which drives inter-city competition. In this sense, residential and commercial development is generating capital for realising industrial development (including service industries) for long-term tax benefits.

Shu et al (2018) use prefectural cities data to study the intensity of land development and confirm that revenues from land did 'drive the land development in cities at the prefectural or higher levels to a considerable extent' (p. 107). But they also reveal that the primary factors are economic growth, population urbanization, and population density, implying that land revenue might not be the only consideration. As will be shown in this paper later, land is often used as a leverage for generating development finance rather than just fiscal income. Even at the rural village and township levels, in order to stimulate economic growth, local carders tried to allocate land development quotas to industrial development. 
This pattern is most visible at the peri-urban areas. Tian (2015) mapped peri-urban areas of Jiangyin and Shunde and identified a pattern of fragmented land uses.

Land-based finance seriously constrained housing affordability and the development of affordable housing. Hu and Qian (2017) examined the impact of land-based finance on the land supply for affordable housing. Using a panel of prefectural cities data, they found that cities with higher reliance on land finance were not willing to devote land for affordable housing. All these studies cover the land development dynamics under land-based finance, their spatial patterns (Tian, 2015) and negative impacts on housing affordability (Hu and Qian 2017), and the environment such as excessive development and higher carbon emission (Zhang and Xu 2017). There is a general consensus about extensive land-based finance and negative impacts.

The limitation of current studies on land-based finance is that they focus on the fiscal contribution (land revenue transfer). The linkage between land and finance is not adequately studied. Revenue generation might be one of many considerations in land development. Very few studies explore the financial operations of land development. Recent studies have highlighted the operations of urban development corporations (Huang \& Chan, 2018; Jiang \& Waley, 2018; Li \& Chiu, 2018; Theurillat, 2017), which rely on land value capture. In addition to the career achievement of government officials and land revenue generation, from the perspective of land financialisation, there might be an additional explanation of financial logic. Land is acquired for its potential as a financial asset to raise capital. This was particularly important for local governments after 2008 when the central government adopted a stimulus package to allow financial instruments to mobilise financial resources. The stimulus package provided easier credit. Therefore, fiscal contribution might not be the consideration (i.e. the traditional view of 'land finance') but rather the competition to securing credit/development finance through land as a financial asset.

This suggests the need to examine the financial operations, namely, the financialisation of land. According to Huang and Du (2018), LGFVs significantly overbid land prices. They found, after controlling for other factors such as land grade and floor area ratio, that LGFVs paid $11 \%$ more than non-LGFVs. They also tend to bid for larger land parcels than non-LGFVs. The high land price creates a larger capacity for the government to leverage land mortgages. Despite the attempt to control housing prices and direct bank loans to developers, land as a financial asset allows developers to raise capital for their projects. As will be shown later, developers' finance increasingly relies on various financial channels, labelled 'self-raised funds', some of which are now banned.

In order to fully understand the relation between finance and land, the next subsection will review the literature of financialization, in particular the role of land in financialization. 


\subsection{Financialisation and land}

Despite the extensive literature on financialisation, few studies focus on the financialisation of land. Political economic studies of land development and more generally the built environment are based on the theory of the 'urbanization of capital' and three capital circuits, of which the built environment accounts for the secondary one (Harvey, 1978). Harvey (1982) further suggests the increasing tendency to treat land as a pure financial asset. Although it is difficult to verify the actual capital flow and switch (Beauregard, 1994), a proliferating literature has emerged since the Global Financial Crisis in 2008 which reveals the specific practices in the subprime mortgage crisis, for example liquidity created through mortgage-backed securities which turned the homes of low-income households into investment assets (Gotham, 2009). Christophers (2010) argues that even with the difficulty of tracing the actual money flow, the contemporary treatment of property is increasingly associated with its financial traits, as in the 'attempts of western-based financiers to extract profit from companies with significant real estate assets by separating those property assets from the operational side of the business in question' (p. 94). Value extraction under 'rentier capitalism' 'seeks to profit from rent rather than from direct productive activity' ( $p$. 106). This confirms the definition of financialisation, i.e. making profits through financial channels rather than production and trade. His example is the rapid expansion of the letting of dwellings in the UK which had risen by $120 \%$ per annum to reach $£ 45$ billion in the 1990 s. For him, the intensification of rent economics is evidence of the financialisation of property.

Focusing on public land in the UK, Christophers (2017) examined the role of the state in financialisation and provided a more nuanced account of treating land as 'pure' financial assets. He stressed that the state did not treat land as financial assets by itself but creates the conditions for the private sector to use land in such a way. The state considers the use value of land and thus tends to differentiate different land sites. While holding some, it releases others to the market to cover its operational costs. Hence the state treats and evaluates public land as an operational asset. He suggested that "the UK state has manifestly contributed to the wide tendency for land to be 'financialized' by that private sector" (p. 20). Ward and Swyngedouw (2018) studied the 'assetization' of land in northwest England and show how the property developer, the Peel Group, gained the land of the Manchester Ship Canal for its land bank and subsequently used this land asset to mobilise capital in the capital market. This asset acquisition occurred in a context in which 'budget-constricted municipalities have become more reliant on monetising land and infrastructure' (p. 5). The land was not intended for future use but rather formed collateral for future income streams to raise capital. This exactly fits the definition of financialisation. In Asia, Shatkin (2016) examined 'land monetization' and its implication for peri-urban areas. He suggests that the rapid escalation of land values allows the state to extract revenue for the government from land development or distribute profit to powerful 
corporations that support the state, thus strengthening and extending state power. Different from the more corporate-led process in the UK, Asian cities demonstrate that 'the state has come to have an increasingly direct stake in land commodification' and in consequence a 'real estate turn in urban politics' (p. 148).

Related but going beyond land, there are now extensive studies on housing financialisation, which is triggered by the global capital surplus (the 'great wall of money') flowing into housing through financial deregulation (Aalbers, 2008), creating new financial markets through making financial/technological changes such as credit scoring which have helped the financialisation of housing (Aalbers, 2016b), mortgage securitization leading to the subprime crisis in the US (Gotham, 2009). Housing financialisation includes the entry of private equity firms, hedge funds and publicly listed real estate firms or real estate investment trusts (REITs) in rental markets (Fields \& Uffer, 2016). Focusing on foreclosed homes turned into rental properties, Fields (2018) shows that the securitizing of rental income has created a new asset class. This is evidence of an expanded role of financial channels in capital accumulation (Krippner, 2005), now moving into social rental housing which was previously outside the operations of financial markets (Wijburg \& Aalbers, 2017). In contrast to the earlier practice of short-term speculation after the financial crisis, REITS and listed funds are interested in long-term possession to continually generate income stream, as shown in Germany (Wijburg, Aalbers \& Heeg, 2018). China also presents the supply-side financialisation of housing, namely, making housing an investment outlet for households through commodification and assetisation (Wu et al., 2020).

\section{Analytical framework}

As land plays such a critical role in China's public finance and local development, existing studies tend to mix up land finance and land financialisation. Furthermore, because land and the public sector are closely related in land development and finance, most studies focus on public finance. This paper adopts an analytical framework that centres on land as a financial asset. The analytical framework includes three important financial instruments applied in land development. These instruments have been applied in different stages of the changing land development process in China, representing subsequent waves of financialisation. While it is worth studying developers' land financialisation tactics, the paper mainly focusses on the government and its related operations because not only the local government plays a significant role in land development (Xu and Yeh, 2009; Xu et al 2009) and financialisation but also main developers are state-owned enterprises. LGFVs act as the primary and major developers in China's land market (Huang and Chan, 2018; Li and Chiu, 2018; Theurillat, 2017; Shen \& Wu, 2017). For these reasons, the paper focuses on the primary land market (land mortgage) and financial mobilisation (LGFVs), and subsequent refinance development debts (Chengtou bonds). 
Land mortgages involving both local government land agencies (land reserve centre) and developers raise capital through land collateral. As for LGFVs, they differ from land agencies and act more in the style of corporations. However, they receive various guarantees from the local government. Their operations may not be generating maximum land income. They fund the infrastructure projects of local government, which may have uncertain financial returns. But their mission is to boost land prices for the government to benefit from land sales. They act in effect as a financial conduit for the local government, which converts bank loans into government revenue. Moreover, the increase in land prices has raised the capacity of capital mobilisation in the financial market, which is increasingly becoming an important method of financing urban development. Thirdly, Chengtou Bonds are issued by LGFVs. They represent a newer wave of financialisation based on land to refinance local debt.

\section{Waves of land financialization}

The reform of China's land system can be divided into four stages ${ }^{1}$. Although the initial stage might not be exactly pertinent to financialisation, the stages generally provide a good account of the discovery of the economic value of land. In the 1980s, collective farmland in rural areas was transferred into a household contract system, which laid down the foundation of rural industrialization and the rise of township and village enterprises. In the 1990s, local governments rapidly released industrial land to attract external investors, starting a process of using land for development. This dynamic was extensively described in the contemporary China land literature (Lin \& Ho, 2005; Su \& Tao, 2017; Yeh \& Wu, 1996). In the 2000s, after housing reform and rapid rural-urban migration driven by exportoriented industries, China started a new phase of land finance, extracting profits from land sales (Lin \& Yi, 2011; Tao et al., 2010), which led to a large scale property boom (Wu, 2015a; Zhao, Zhan, Jiang, \& Pan, 2017).

These three stages have been well addressed under the literature of land finance. But the stage of land financialization has not been fully studied.

The fourth stage started with the Global Financial Crisis in 2008. In this ongoing stage, we see the linkage between land and finance. Land goes beyond its fiscal contribution and acts in capital mobilisation, as shown in Liu's investigation:

"[the local officials interviewed] no longer cared for how much the land can be sold but look for how much the financing platform can raise. The platforms extended

\footnotetext{
${ }^{1}$ Professor Shouying Liu at People's University discussed these stages in his public lecture, 4 March 2017, thepaper.cn.; also see Liu (2017).
} 
from the provincial levels to township levels. The developments have shifted from possible profitable projects to projects with great uncertainty. From this perspective, the whole system of financial platforms became chaotic, basically relying on the platform to register capital and use land to raise capital" (Liu, public lecture, 4 March 2017, thepaper.cn).

If the purpose is to use land as leverage to obtain investment rather than revenue from land sales, then the behaviour of the local government will try to boost land values by limiting the amount of land released to the market. In addition to the central policy of protecting agricultural land, the local government indeed changed its tactics in land sales. Instead of seeking urban sprawl as in the earlier stage, new land development often takes a compact form through transit-oriented development (TOD) and new towns (Shen \& Wu, 2017; Shen and $\mathrm{Wu}, 2019)$. This spatially consolidated form of development, beyond the rhetoric of sustainable development and land protection, allows a single developer to 'master plan' and perform overall control of land development. This single primary developer is often a stateowned enterprise under the local government, in fact, a special purpose vehicle (SPV), or as widely known in China a local government platform (LGP) or local government financial vehicle (LGFV).

The year 2008 marked the end of China's world factory model and opened an era of 'financialisation'. Land was not used as a means to attract more industrial investment because of the constraint of overseas markets. Instead, in response to a stimulus package and the infrastructure-driven approach, local governments began to use land more as collateral to gain access to the credit made available under fiscal expansion.

The cost of land acquisition has significantly increased over years. While local governments were able to acquire relatively cheaper rural land for sale in the past, this is no longer the case. Compensation and demolition costs increased to $60 \%$ of the total development cost in 2015 (Table 1). The initial development cost leading to land sale accounted for almost $80 \%$ of total revenue. In other words, even before the land can be put on the land market, $80 \%$ of the expected income has to be spent, leaving a 'profit' margin of $20 \%$. For developers, some additional infrastructure development is still needed after they obtain the land. While the land sale brought 3.366 trillion Yuan to local revenue in 2015, net income was only 681 billion Yuan after huge land costs. This indicates that land sales are less profitable than commonly imagined. The rising compensation cost is due to social resistance and the reinforcement of compensation standards. To avoid large conflicts and maintain social stability, local governments tend to compensate existing landowners more generously. Given such huge costs associated with land acquisition, the motivation of land development is arguably less associated with land profits as a contribution to local fiscal budgetary deficits, as suggested by the existing body of literature on land finance. The compensation cost, to some extent, can be seen as development expenditure which improves living 
standards in the area to be developed, and hence offsets some expenditure in these areas. But the ability to use the land acquired to obtain land mortgages stimulates local development to boost land prices. In some of the worst cases this becomes necessary, as the new loans are needed to pay back previous debts or even just the interest on them. In $2015,490,800$ hectares of land were used as collateral for 11.33 trillion Yuan. The total amount of land mortgages is almost twice the land revenue. What is more attractive for the local government is its ability to invest during the fiscal stimulus policy and its accompanying credit liquidity.

$<$ Table 1 is about here $>$

There have been major policy changes since 2016. The potential risk of land mortgages based on land reserves is that the land sale might not be realised as a result of a land market downturn. Therefore, mortgages based on expected land income may be at risk. Because of concern over the financial risks, the central government has tightened control over land mortgages and land reserve centres. Only land with deeds (after land purchase) can be used as collateral. Enterprises are forbidden to use bank loans or other financial instruments to purchase land. In 2016, the central government issued No.4 Decree of Finance Regulation Policy to regulate land reserves and financial management. It requires land reserve centres to maintain the status of public-purpose agencies. All capital mobilisation, land and infrastructure construction and secondary land development (for the profitable market) functions need to be transferred into separate enterprises. Land acquisition by government has to be funded by the fiscal budget. The policy in effect abolished the financial function of land reserve agencies.

The next three sections will address three financial instruments applied in land financialization.

\section{Land mortgage}

The land mortgage is the primary method of accessing finance for landowners. So far there are no nationwide data, as the cadastral system has only been established since 2016. According to a survey of 84 cities by the Ministry of Land and Resources, land mortgages have significantly increased. In 2008, 1.81 trillion Yuan of land mortgages were obtained from land collateral of 165,800 hectares; In 2014, land mortgages increased to 9.51 trillion Yuan, with land collateral of 451,000 hectares (Ministry of Land and Resources, 2017, p. 6). Because of the appreciation of land values, the intensity of land mortgages increased. In 2014, 210.9 million Yuan of land mortgages were collected per hectare of land, an increase of $93 \%$ during the period from 2008 to 2014 . This means that the increase in land values has provided more capital for urban development, in addition to the expansion of land 
collateral. The expansion of land mortgages is due to the establishment of land reserve centres.

Land mortgage has become more attractive since the adoption of the fiscal stimulus package in 2008. Faced with a policy involving greater capital liquidity, the ability to capture this capital liquidity relied on using land collateral. The operation is therefore different from what is commonly known as an entrepreneurial city attracting external investors. Rather, it is an operation within a financialised policy landscape. More land reserve centres have been set up to capture this opportunity to use land reserves to borrow bank loans for local development. These land reserve centres thus act in a very similar way to LGFVs. What is more powerful for land reserve centres is that they were able to mortgage the land before it received title.

The method land mortgage was actually invented initially in Shanghai's Pudong New District, known as 'virtual capital circulation' (zijin kongzhuan) (Wu, 2002). The land itself, rather than fiscal investment, was used as government input in Pudong's development. The government allocated undeveloped land to four development corporations in Pudong. At the time of transfer, the land had no proper deeds but only the guarantee that the development corporations would have the right to develop them and sell them in the land market. In terms of actual capital input, this was non-existent and hence 'virtual'. Land mortgages provided the initial capital, betting on future income streams from land development. The actual operation was even more interesting in Lujiazui, given the absence of a mature land market and land mortgage practice at the time. The government actually played an important role with a helping hand. The major input was a cheque from the government for the development corporation but this was not 'cashed' at the bank. It was in fact a credit guarantee from the government. But the credit guarantee assigned a price tag to the land, as this was the price that the local government was willing to pay for it. Thus, the land became collateral for bank loans to conduct land development. After the success of the land income stream, the cheque was returned to the government and has never been cashed because the development corporation paid back the loan from land proceeds. In this sense, there was a virtual circulation of capital.

Immediately after the Global Financial Crisis, local governments expanded their land reserves in order to reach their investment targets as specified in the stimulus package. In other words, local governments were not competing for external investment but rather for the promised credit which could not be provided without collateral because a local government is not allowed to issue government bonds. The common practice was to specify the land plot that was planned to be sold and developed for the future land market, and to use the land reserve to gain bank loans. Therefore, not only has the overall size of land mortgages significantly increased, but also the proportion of land reserve mortgages in total land mortgages has increased from 4\% in 2008 to a peak of $16.5 \%$ in 2011. From 2011, the 
proportion of land reserve mortgages declined, because land mortgages based on land reserves put significant pressure on the local government, which could not maintain the speed of releasing land reserves into the market because of the economic downturn and the tightening of the real estate market by the central government. The difficulty of selling the land reduced the land supply. In fact, one major reason may be that land mortgages based on land reserves were not effectively used to clear the land and make its sale possible. Thus, the local government would need to pay back the land mortgage before it could be sold, but it did not have the financial capacity to return the land mortgage. This forms a bottleneck in land supply. On the other hand, land values continue to increase due to the inflow of capital into a built environment with a constrained land supply. The developers or enterprises owning the land were able to use the land to obtain land mortgages, leading to the expansion of overall land mortgages but a relative reduction in reserve land mortgages. This expansion of land mortgages also indicates the concrete land conduit through which fiscal expansion without actual capital injection can be transmitted into urban development.

Among land collateral in $2014,14.17 \%$ of the total capital was based on land reserves owned by land reserve centres. This suggests that land mortgages provide an important source for related infrastructure development before land is released to the land market. The local government (or more precisely its subsidiary land agency) can use land to obtain mortgages to fund other projects. Land reserve centres thus play a role not only in land acquisition and auction but also in capital mobilisation. The involvement of land reserves in land mortgages is a clear evidence for land-based financing. Since 2008, the use of land reserves for mortgages has significantly increased (see Figure 1).

$<$ Figure 1 about here>

Land agencies use land mortgages to conduct initial development such as demolition and infrastructure construction and then release the land to the primary land market. Because the primary land market is monopolized by the local government, the land price has been boosted. Now, the local government might not intend to maximize its total income from land sales but rather to use limited land sales to increase land prices thus enabling a greater amount of land mortgage to be obtained from the land reserves. There has been a major shift from enlarging the quantity of land sales to enhancing the intensity of land mortgages.

In practice, the local land authority specifies land usage and the term of land leases and then grants the land use permit to the land reserve centre (in fact, in this case they play a dual role of land acquisition and reservation on the one hand and financial vehicle on the other). The land reserve centre uses this permit to obtain a loan for initial land development, leading to the sale of the land. Strictly speaking, this is not land collateral based on ownership but a construction loan based on a guarantee from the local government that this plot of land will be allowed to be sold in the land market once the 
initial construction is complete. The land mortgage ratio (the value of loan to the value of land) has also been increasing but recently declined to $44 \%$ (Figure 2). This means that based on an expected land sale price, nearly half of the value could be made into a loan. The 'fixed asset' is thus becoming liquid.

<Figure 2 about here>

In terms of mortgage providers, in China banks are still the source of land mortgages. In $2014,74.7 \%$ of land mortgages were provided by major banks, including the Bank of China, the Industrial and Commercial Bank of China, the Construction Bank of China, the China Agricultural Bank and the Bank of Transport which accounted for 38\% of land mortgages. In terms of mortgage receivers, shareholding companies and state-owned companies accounted for $33.9 \%$ and $16.8 \%$ respectively; land reserve centres accounted for $15.0 \%$ and the private sector for $8.8 \%$, while individuals and self-employed businesses used only $0.93 \%$ and $0.47 \%$ of total mortgages. This indicates that land mortgaging is mainly an enterprise behaviour.

\section{Local government financial vehicles}

Local government financial vehicles (LGFVs) are also sometimes known as local financing platforms (LFPs) (Pan et al., 2017). According to the 'official' definition (The State Council 2010, Notice of the State Council on Certain Issues Related to Strengthening the Regulation of Local Government Financing Vehicle Corporations), LGFVs are 'economic entities with independent legal personality, which are established by local governments and their departments and agencies through fiscal appropriation or injection of assets such as land and equity, to perform the functions of financing government-invested projects' (Fan, 2016, p. 73). These include various kinds of urban development and investment corporations (UDICs), investment group corporations, state-owned asset management corporations and industry-specific investment corporations.

The promulgation of the document shows that the central government had realised the problem of LGFVs and related local government debts. However, because of the fiscal gap between local revenue and expenditure as well as the investment-driven development approach, LGFVs remain as major organisers for local infrastructure and public services projects, which may not generate sufficient profit to be taken on by the private sector. A government guarantee is deemed to be a critical factor for bank loans which may eventually be paid back through fiscal income.

Besides the initial capital injection, land is the most common and effective asset for LGFVs because of the local state's monopoly on land resources and the primary land market. LGFVs eventually set up the linkage between infrastructure development and land value 
capture. Infrastructure investment is not profitable. But allocating land along with infrastructure projects allows LGFVs to capture future land values typically through the rail property model which has been adopted in Japan and Hong Kong. This model builds upon future land value appreciation. The model is also extensively used in new town development where the key developer can benefit from comprehensive and packaged development.

The use of bank loans to fund land reserves and land purchases was indeed problematic, as based on the land, banks essentially funded the initial preparation for the land sale, while they further funded LGFVs to purchase land at a higher price, which eventually turned into land revenue for the local government. In short, because direct finance is not allowed for the local government, indirect land-based financing became the dominant approach. Because of the large contribution of LGFVs to local finance, Fan (2016) suggests that the Chinese state shows some features of a 'rent-state' and maintains some trace of an 'ownerstate', rather than a 'tax-state'. Apart from tax, government revenue draws from the profits of state-owned enterprises and rents. Land-derived rents have defined some of the behaviour of the local state (Huang \& Du, 2018; Tao et al., 2010) which pursues high land prices while maintaining its political alignment with central government policy.

LGFVs are major instruments for raising funding for the local government. Figure 3 shows the financial contribution made by LGFVs to land conveyance fees. Huang and Du (2018) described the aggressive land purchase behaviour of LGFVs which pushes up land prices. The volume of land purchases by LGFVs increased significantly after 2008. The figure also shows that the ratio of LGFVs' contribution to total land conveyance fees was just over $4 \%$, which indicates that the actual financial contribution is rather modest. The significance of LGFVs is not their financial contribution to local finance through land purchase but rather in their capacity for capital mobilisation - largely through direct finance from banks. From 2008, the number of LGFVs increased from 306 in 2007 to 8221 in 2009 (Pan et al., 2017, p. 902). While it is difficult to estimate the amount of loans borrowed by LGFVs, because LGFVs have close links with local government it is possible to understand the significance from local government debts. In 2013, the National Audit Office (NAO) published a report on local debt, which is actually the latest report available as no further report has been published. The report suggests that local government debt amounted to 10.88 trillion Yuan, with other guarantees of 2.66 trillion Yuan and possible implicit debt of 4.39 trillion Yuan. This is a total of 17.89 trillion Yuan (Table 2). As this was before the launch of a loan-to-bond swap programme in 2015, the bank loans were largely incurred by LGFVs. Using the WIND dataset and NAO sources, Bai, Hsieh and Song (2016) estimated that the total debt of LGFVs amounted to 22.9 trillion Yuan in 2014 as 'official lending'; but all lending listed in WIND covering non-official loans as well reached 37-38 trillion Yuan. Including the smaller loans not listed in WIND, this means that the total liability of LGFVs reached an astonishing 47.7 trillion Yuan. So, compared with the 190.9 billion Yuan of land purchase fees, LGFVs are 
more a financial vehicle than a contributor to local revenue. They are significant in financial rather than fiscal terms.

$<$ Figure 3 is about here $>$

<Table 2 about here>

Increasing LGFV debt is essentially local government debt. Because of the scale of this debt, possible bankruptcy would lead to serious problems for state banks. In 2015, the central government launched loan-to-bond swap programmes, further opening the capital market and leading to an era of shadow banking (Bai et al., 2016). The policy aim now is to convert LGFVs that have profit into 'normal' enterprises, stripping off their financing functions. In other words, they should not raise funding for the government and public infrastructure projects. For non-profit and public services projects, the fiscal budget should cover their development through public and private partnership. The municipal government is allowed to issue municipal bonds (as government bonds) with the approval of the Ministry of Finance. The objective is to separate LGFV debts and local government debts, turning the former into corporate debts.

\section{Chengtou Bonds}

The Chengtou Bond can be literally translated as 'urban investment bond' or 'urban construction and investment bond'. Some refer to this as a 'municipal corporate bond' (Amstad and He, in press; Ang et al., 2016; Chen et al., 2017) because they are issued by LGFVs to support infrastructure development, so legally they are corporate bonds. What makes them special is an implicit guarantee offered by the local government. However, the new policy forbids government guarantees for Chengtou Bonds in order to restrain local government debts and separate government debts from corporate debts. In practice, land is a major form of additional guarantee to replace other guarantees from the local government. Chengtou Bonds accounted for $75.5 \%$ of total enterprise bonds at the end of 2017 (Amstad and He, in press).

Figure 4 shows the growth of Chengtou Bonds since 2002. Outstanding Chengtou Bonds increased from just 12.6 billion Yuan in 2002 to 280.9 billion Yuan in 2008 but jumped to 4.95 trillion Yuan in 2014 (Ang, Bai, \& Zhou, 2016). This is a major increase due to the large increase in bank loans after 2008. Bank loans generated financial pressure in 2012, four years after the fiscal stimulus package. Chengtou Bonds were promoted to find additional capital sources to cope with the pressure to refinance bank loans. In 2018, the total issuance of Chengtou Bonds was 2.46 trillion Yuan. However, because of the maturity of a large amount of bonds issued previously, the outstanding total of Chengtou Bonds decreased by 
$16.4 \%$, suggesting that the Chengtou Bond is no longer a sustainable source for financing urban development.

$<$ Figure 4 is about here $>$

For a Chengtou Bond, an effective guarantee is its land assets, besides other government, corporate or share guarantees. In 2014, about $41 \%$ of credit guarantees came from land assets possessed by LGFVs (Ministry of Land and Resources, 2017). For investors, a land guarantee brings much certainty and reduces the risk of infrastructure projects, because even if the project fails the assets possessed by the project could still be valuable. Also, the future revenue stream from land is more certain than the profit from infrastructure, if land sales proceed. Recent studies show the intrinsic linkage between the yields of Chengtou Bonds and the percentage of real estate to local GDP (Ang et al., 2016). The higher the percentage of real estate in GDP, the lower the yield as it has a relatively lower risk because of the booming land market. These findings reveal that the issuance of Chengtou Bond relies on land and property assets.

The introduction of Chengtou Bonds suggests a new pattern of land infrastructure leverage which is different from the findings of earlier studies (Lu \& Sun, 2013; Tsui, 2011). Leverage now allows the capital market to finance urban development. Regarding primary holders of Chengtou Bonds, commercial banks accounted for 31.0\% (indirectly through trusts under these banks), funds for $24.8 \%$, and insurance companies for $21.4 \%$ (Ang et al., 2016). The trusts, funds and insurance companies represent 'shadow banking' as the loans are not listed in their balance sheets. Wealth management products (WMPs) have been created by these financial institutions which invested in Chengtou Bonds and sell WMPs to consumers. Chen, He and Liu (2017) estimate that $62 \%$ of Chengtou Bonds were invested by WMPs in 2016. This means that the link between Chengtou Bonds and WMPs serves as a conduit from land financialisation to the financing of urban development in China.

Figure 5 shows the new dynamics after the introduction of Chengtou Bonds. At the peak of 2015, WMPs became a major source for LGFV funding. It is hard to exactly identify the route because besides the route of investment in Chengtou Bonds, WMPs can also invest in other trusts which further invest in LGFV projects, and Chengtou Bonds can also receive investment from trusts, creating a sophisticated web of flows. Therefore, although Chengtou Bonds have been promoted as a more transparent and regulated method to refinance the debt pressure on LGFVs, their linkages with WPMs and trusts make them more opaque in terms of financial flows. They are also critical for financial stability as they provide a foundation for WPMs and trust investment. So far Chengtou Bonds have not seen any defaults.

$<$ Figure 5 is about here $>$ 


\section{Implications for financing urban development}

China has experienced a sustained real estate boom since 2001. Classic political economic studies on land development explain the boom through deindustrialisation, gentrification and urban development, and an underlying capital switch from the primary to the secondary capital circuit. Indeed, two large waves of real estate booms in China were triggered by the Asian financial crisis in 1997 and the Global Financial Crisis in 2008, during which Chinese export-oriented industries experienced tremendous difficulties. Economic and financial crises led to redundant production capacity and symptoms of overaccumulation. The surplus capital needed to find an investment outlet, and in this case housing and land have become more profitable assets. The inflow of capital led to further asset appreciation (Wu, 2015a).

We can better understand the dynamics of investment-driven asset appreciation from the perspective of land financialisation. Land is used as collateral for land mortgages, which justifies credit expansion. Various financial channels have been invented and deployed, including land reserve centres financing land development prior to land supply (auction), bank loans to purchase the land, LGFVs using land assets for development loans, developers and enterprises using land mortgages for land development or operational loans, and finally the issuance of Chengtou Bonds to refinance LGFV debts. Land collateral and transactions require money supply and credit provision; injection of capital and land development raises asset values, which intensifies the capacity to raise more credit. Without land and a consequent property asset pool, credit supply would lead to super inflation. It has been suggested as common wisdom that China's rapid M2 has led to a real estate bubble (Zhao et al., 2017). Understanding land financialisation reveals the other side of the same coin - land financialisation associated with money creation, which is referred to as 'capitalization of urban land' (Lin \& Yi, 2011). While Lin and Yi (2011) and Tao et al. (2010) paid more attention to using land to attract foreign and industrial investment, this paper highlights the impact of land financialisation on internal money creation. Turning land into assets has made it possible to release money for urban development. It is the financialisation of land that allows local governments to associate asset values and income streams from future land sales and tax increments with their capacity to leverage capital and finance urban development. The consequence is a significant $M 2$ increase and investment in fixed assets (Figure 6 and 7).

$<$ Figure 6 and 7 are about here>

For the national and local economies, land financialization distorted local government behaviours and created significant financial risks. Local governments enthusiastically set up 
LGFVs to mobilise financial resources and fund large-scale infrastructure and mega urban projects such as new towns (Shen and $\mathrm{Wu}, 2017)$. This is essentially an approach of 'development by borrowing' (Pan et al., 2017; Shatkin, 2016). Because the asset value has been inflated, these projects have an illusion to refinance them through land value capture. But in reality, many encountered financial difficulties, which forced the central government to adopt a further financial innovation, for example, using the bond market to expand and extend their financial viability.

\section{Conclusion}

While the contribution of land sales to local public finance in China has been widely documented and referred to as 'land finance' (or more precisely 'land-based public finance') which indicates its high reliance on land revenue (Lin, 2014; Su \& Tao, 2017; Tao et al., 2010), the financialisation of land itself has not been subject to close scrutiny. Prior to emerging research on financialisation in the post-global financial crisis, the political economic analysis of capitalist spatial production (land development) suggested that land becomes a 'financial asset' through 'urbanization of capital' (Harvey 1982). More generally, the built environment is seen as an outlet for surplus capital. More recent studies have begun to reveal how capital arrives and becomes established in cities, which involves financial negotiations and deals (Christophers, 2017; Theurillat et al., 2016a).

This paper examines the linkage between land financialisation and urban development in China and emphasizes the specific conduits through which capital flows into land and the role of land in financing urban development. In this sense, it is not about the coming of 'the wall of money' in the global capital market seeking safe investment outlets (Aalbers, 2016b; Fernandez, Hofman, \& Aalbers, 2016) or creating liquidity through securitization of mortgages (Gotham, 2009). The paper shows how land financialisation in China has made it possible to expand credit and consequently allowed local governments to invest in urban development. Similarly, in the housing sector, assetization formed an integral component of China's financialization of urban development and made the development model possibl (Wu et al., 2020). What is significant is the strategy behind such a process of land financialisation. In other words, land financialisation has been deployed by the state to cope with the Global Financial Crisis, which seriously exposed the weakness of China's exportoriented economy. However, the application of these financial instruments has created further financial risks.

The paper argues that there is a need to think of capital switching as a spatial fix not only due to declining profit rates as shown in capital over-accumulation in Western deindustrialization and shrinking Chinese export industries but also because of a series of specific land institutions that have paved the way to absorbing capital. Here, we suggest that these institutions include China's land management system, and local government 
financial vehicles, and the subsequent endeavours to refinance the debts caused by initial land development after the fiscal stimulus package. Land financialisation has played a critical role in triggering and reinforcing money supply. Some specific conduits have been formed under state entrepreneurialism ( $W u, 2015 b ; W u, 2018)$, such as local government financial vehicles as state-owned enterprises engaged mostly in land and infrastructure development. The Chengtou Bond has been expanded further to refinance the loans made to LGFVs. Moreover, as shown in the paper, land financialisation in China occurs in financial depression (state-controlled capital market and interest rates) and land monopoly (local municipality controls the primary land supply) rather than neoliberalisation or financial deregulation. However, underlying financial risks have not been well understood. What is more revealing here is that in China, the perceived financial risks have propelled the Chinese state to adopt 'new financial innovations' to postpone the negative impacts on the real economy. However, land financialization distorted land management and local government behaviours and created many mega urban projects and large-scale infrastructure projects based on land financing approaches. As the land price becomes stable, the financial viability would need to be re-scrutinised, as shown in recent high debt ratios of some LGFVs and their projects.

\section{Reference}

Aalbers, M. B. (2008). The financialization of home and the mortgage market crisis. Competition and Change, 12(2), 148-166.

Aalbers, M. B. (2016a). Corporate financialization. International Encyclopedia of Geography: People, the Earth, Environment and Technology: People, the Earth, Environment and Technology, 1-11.

Aalbers, M. B. (2016b). The financialization of housing: A political economy approach. London: Routledge.

Amstad, M., He, Z., in press. Chinese bond market and interbank market. In: Amstad, M., Sun, G., Xing, W. (Eds.), Handbook on Chinese financial system. Princeton University Press, Princeton, NJ.

Ang, A., Bai, J., \& Zhou, H. (2016). The great wall of debt: Real estate, corruption, and Chinese local government credit spreads. Georgetown McDonough School of Business Research Paper (2603022), 15-57.

Bai, C.-E., Hsieh, C.-T., \& Song, Z. M. (2016). The long shadow of a fiscal expansion. National Bureau of Economic Research, Paper No. 22801.

Beauregard, R. A. (1994). Capital switching and the built environment: United States, 197089. Environment and Planning A, 26, 715-732.

Chen, Z., He, Z., \& Liu, C. (2017). The financing of local government in China: Stimulus loan wanes and shadow banking waxes. National Bureau of Economic Research, No. w23598. 
Christophers, B. (2010). On voodoo economics: theorising relations of property, value and contemporary capitalism. Transactions of the Institute of British Geographers, 35(1), 94-108.

Christophers, B. (2017). The state and financialization of public land in the United Kingdom. Antipode, 49(1), 62-85.

Fan, L. (2016). Quenching thirst with poison? Local government financing vehicles: past, present, and future. In B. L. Liebman \& C. J. Milhaupt (Eds.), Regulating the visible hand? (pp. 69-84). Oxford: Oxford University Press.

Fernandez, R., Hofman, A., \& Aalbers, M. B. (2016). London and New York as a safe deposit box for the transnational wealth elite. Environment and Planning A: Economy and Space, 48(12), 2443-2461.

Fields, D. (2018). Constructing a new asset class: Property-led financial accumulation after the crisis. Economic Geography, 94(2), 118-140.

Fields, D., \& Uffer, S. (2016). The financialisation of rental housing: a comparative analysis of New York City and Berlin. Urban Studies, 53(7), 1486-1502.

Gotham, K. F. (2009). Creating liquidity out of spatial fixity: the secondary circuit of capital and the subprime mortgage crisis. International Journal of Urban and Regional Research, 33(2), 355-371.

Harvey, D. (1978). The urban process under capitalism. International Journal of Urban and Regional Research, 2, 101-131.

Harvey, D. (1982). The limits to capital. Oxford: Blackwell.

Hu, F.Z.Y. \&, Qian J. (2017) Land-based finance, fiscal autonomy and land supply for affordable housing in urban China: A prefecture-level analysis. Land Use Policy 69: 454-460.

Huang, D., \& Chan, R. C. (2018). On 'land finance' in urban China: Theory and practice. Habitat International, 75, 96-104.

Huang, Z., \& Du, X. (2018). Holding the market under the stimulus plan: Local government financing vehicles' land purchasing behavior in China. China Economic Review. 50, 85-100.

Jiang, Y., \& Waley, P. (2018). Shenhong: The Anatomy of an Urban Investment and Development Company in the Context of China's State Corporatist Urbanism. Journal of Contemporary China, 1-15.

Krippner, G. R. (2005). The financialization of the American economy. Socio-economic review, 3(2), 173-208.

Li, H., \& Zhou, L.-A. (2005). Political turnover and economic performance: the incentive role of personnel control in China. Journal of Public Economics, 89(9), 1743-1762.

Li, J., \& Chiu, L. R. (2018). Urban investment and development corporations, new town development and China's local state restructuring-the case of Songjiang new town, Shanghai. Urban Geography, 39(5), 687-705. 
Lin, G. C. S. (2014). China's landed urbanization: neoliberalizing politics, land commodification, and municipal finance in the growth of metropolises. Environment and Planning A, 46, 1814-1835.

Lin, G. C. S., \& Ho, S. (2005). The state, land system, and land development processes in contemporary China. Annals of Association of American Geographers, 95(2), 411436.

Lin, G. C. S., \& Yi, F. (2011). Urbanization of capital or capitalization on urban land? Land development and local public finance in urbanizing China. Urban Geography, 32, 50 79.

Liu, S. (2017). China's land reform: the first and second part. International Economic Review (in Chinese), 5(5), 29-56.

Liu, Y., Fan, P., Yue, W., \& Song, Y. (2018). Impacts of land finance on urban sprawl in China: The case of Chongqing. Land Use Policy, 72, 420-432.

Lu, Y., \& Sun, T. (2013). Local government financing platforms in China: A fortune or misfortune? IMF Working Paper No. 13-243.

Ministry of Land and Resources. (2017). Land mortgage and capital mobilization (in Chinese). Beijing: China Dadi Press.

Pan, F., Zhang, F., Zhu, S., \& Wójcik, D. (2017). Developing by borrowing? Inter-jurisdictional competition, land finance and local debt accumulation in China. Urban Studies, 54(4), 897-916.

Shatkin, G. (2016). The real estate turn in policy and planning: Land monetization and the political economy of peri-urbanization in Asia. Cities, 53, 141-149.

Shen, J., \& Wu, F. (2017). The suburb as a space of capital accumulation: The development of new towns in Shanghai, China. Antipode, 49(3), 761-780.

Shen, J., \& Wu, F. (2019). Paving the way to growth: transit-oriented development as a financing instrument for Shanghai's post-suburbanization. Urban Geography (on-line first).

Shu, C., Xie, H.L., Jiang, J.F., \& Chen, Q.R. (2018) Is urban land development driven by economic development or fiscal revenue stimuli in China? Land Use Policy 77: 107115.

Su, F., \& Tao, R. (2017). The China model withering? Institutional roots of China's local developmentalism. Urban Studies, 54(1), 230-250.

Tao, R., Su, F. B., Liu, M. X., \& Cao, G. Z. (2010). Land leasing and local public finance in China's regional development: Evidence from prefecture-level cities. Urban Studies, 47(10), 2217-2236.

Theurillat, T. (2017). The role of money in China's urban production: the local property industry in Qujing, a fourth-tier city. Urban Geography, 38(6), 834-860.

Theurillat, T., Lenzer Jr, J. H., \& Zhan, H. (2016). The increasing financialization of China's urbanization. Issues \& Studies, 52(04), 1640002.

Theurillat, T., Vera-Büchel, N., \& Crevoisier, O. (2016). Commentary: From capital landing to urban anchoring: The negotiated city. Urban Studies, 53(7), 1509-1518. 
Tian, L. (2015). Land use dynamics driven by rural industrialization and land finance in the peri-urban areas of China: The examples of Jiangyin and Shunde. Land Use Policy, 45, 117-127.

Tsui, K. Y. (2011). China's infrastructure investment boom and local debt crisis. Eurasian Geography and Economics, 52(5), 686-711.

Ward, C., \& Swyngedouw, E. (2018). Neoliberalisation from the ground up: Insurgent capital, regional struggle, and the assetisation of land. Antipode. 50(4), 1077-1097.

Weber, R. (2010). Selling city futures: the financialization of urban redevelopment policy. Economic Geography, 86(3), 251-274.

Wijburg, G., \& Aalbers, M. B. (2017). The alternative financialization of the German housing market. Housing Studies, 32(7), 968-989.

Wijburg, G., Aalbers, M. B., \& Heeg, S. (2018). The Financialisation of Rental Housing 2.0: Releasing Housing into the Privatised Mainstream of Capital Accumulation. Antipode.

Wong, C. (2013). Paying for urbanization in China: Challenges of municipal Finance in the Twenty-First Century. In R. Bahl, J. Linn, \& D. Wetzel (Eds.), Financing Metropolitan Governments in Developing Countries (pp. 273-308). Cambridge, MA: Lincoln Institute for Land Policy.

Wu, F. (2002). China's changing urban governance in the transition towards a more marketoriented economy. Urban Studies, 39(7), 1071-1093.

Wu, F. (2015a). Commodification and housing market cycles in Chinese cities. International Journal of Housing Policy, 15(1), 6-26.

Wu, F. (2015b). Planning for growth: urban and regional planning in China. London, Routledge.

Wu, F. (2018). Planning centrality, market instruments: governing Chinese urban transformation under state entrepreneurialism. Urban Studies, 55(7), 1383-1399.

Wu, F., Chen, J., Pan, F., Gallent, N., \& Zhang, F. (2020). Assetisation: the Chinese path to housing financialisation. Annals of the American Association of Geographers (in press).

Wu, Q. Li, Y.L., \& Yan, S.Q. (2015) The incentives of China's urban land finance. Land Use Policy 42: 432-442.

Wu, W. (2010). Urban infrastructure financing and economic performance in China. Urban Geography, 31(5), 648-667.

Xu, J., \& Yeh, A. G.-O. (2009). Decoding urban land governance: state reconstruction in contemporary Chinese cities. Urban Studies, 46(3), 559-581.

Xu, J., Yeh, A. G.-O., \& Wu, F. (2009). Land commodification: new land development and politics in China since the late 1990s. International Journal of Urban and Regional Research, 33(4), 890-913.

Ye, L., \& Wu, A. M. (2014). Urbanization, land development, and land financing: evidence from Chinese cities. Journal of Urban Affairs, 36, 354-368. 
Yeh, A. G. O., \& Wu, F. (1996). The new land development process and urban development in Chinese cities. International Journal of Urban and Regional Research, 20(2), 330353.

Zhang, W. \& Xu, H. (2017) Effects of land urbanization and land finance on carbon emissions: A panel data analysis for Chinese provinces. Land Use Policy 63: 493-500.

Zhao, S. X., Zhan, H., Jiang, Y., \& Pan, W. (2017). How big is China's real estate bubble and why hasn't it burst yet? Land Use Policy, 64, 153-162. 
Table 1 land development cost, land mortgage, and land revenue

\begin{tabular}{|l|l|l|l|l|}
\hline & $\begin{array}{l}\text { Land } \\
\text { development in } \\
\text { total cost (\%) }\end{array}$ & $\begin{array}{l}\text { Gross land } \\
\text { revenue (trillion } \\
\text { Yuan) }\end{array}$ & $\begin{array}{l}\text { Net land } \\
\text { revenue (billion } \\
\text { Yuan) }\end{array}$ & $\begin{array}{l}\text { Land mortgage } \\
\text { (trillion Yuan) }\end{array}$ \\
\hline 2008 & 56.1 & 0.944 & 436.3 & 1.810 \\
\hline 2009 & 53.8 & 1.424 & 658.3 & 2.585 \\
\hline 2010 & 58.4 & 2.939 & 1221.6 & 3.530 \\
\hline 2011 & 71.8 & 3.347 & 942.3 & 4.800 \\
\hline 2012 & 78.3 & 2.888 & 626.1 & 5.950 \\
\hline 2013 & 81.7 & 4.125 & 755.1 & 7.760 \\
\hline 2014 & 79.1 & 4.294 & 898.8 & 9.510 \\
\hline 2015 & 79.8 & 3.365 & 681.3 & 11.330 \\
\hline
\end{tabular}

Source: Ministry of Land and Resources, 2014, 2016; Liu, 2017. 
Table 2 The local government debt (trillion Yuan)

\begin{tabular}{|l|l|l|l|l|}
\hline & Full obligation & $\begin{array}{l}\text { Guaranteed } \\
\text { liability }\end{array}$ & $\begin{array}{l}\text { Contingent } \\
\text { liability }\end{array}$ & Total debt \\
\hline Bank loan & 5.525 & 1.909 & 2.685 & 10.119 \\
\hline $\begin{array}{l}\text { Build and } \\
\text { transfer }\end{array}$ & 1.215 & 0.047 & 0.215 & 1.476 \\
\hline Bond & 1.166 & 0.167 & 0.512 & 1.846 \\
\hline $\begin{array}{l}\text { Among which } \\
\text { Chengtou bond }\end{array}$ & 0.459 & 0.081 & 0 & 0.664 \\
\hline Trust & 0.762 & 0.253 & 0.410 & 1.425 \\
\hline Others & 1.759 & 0.209 & 0.517 & 2.361 \\
\hline Total & 10.886 & 2.666 & 4.339 & 17.891 \\
\hline
\end{tabular}

Source: National Audit Office (NAO) 2013 reports; revised from Chen et al (2017). 


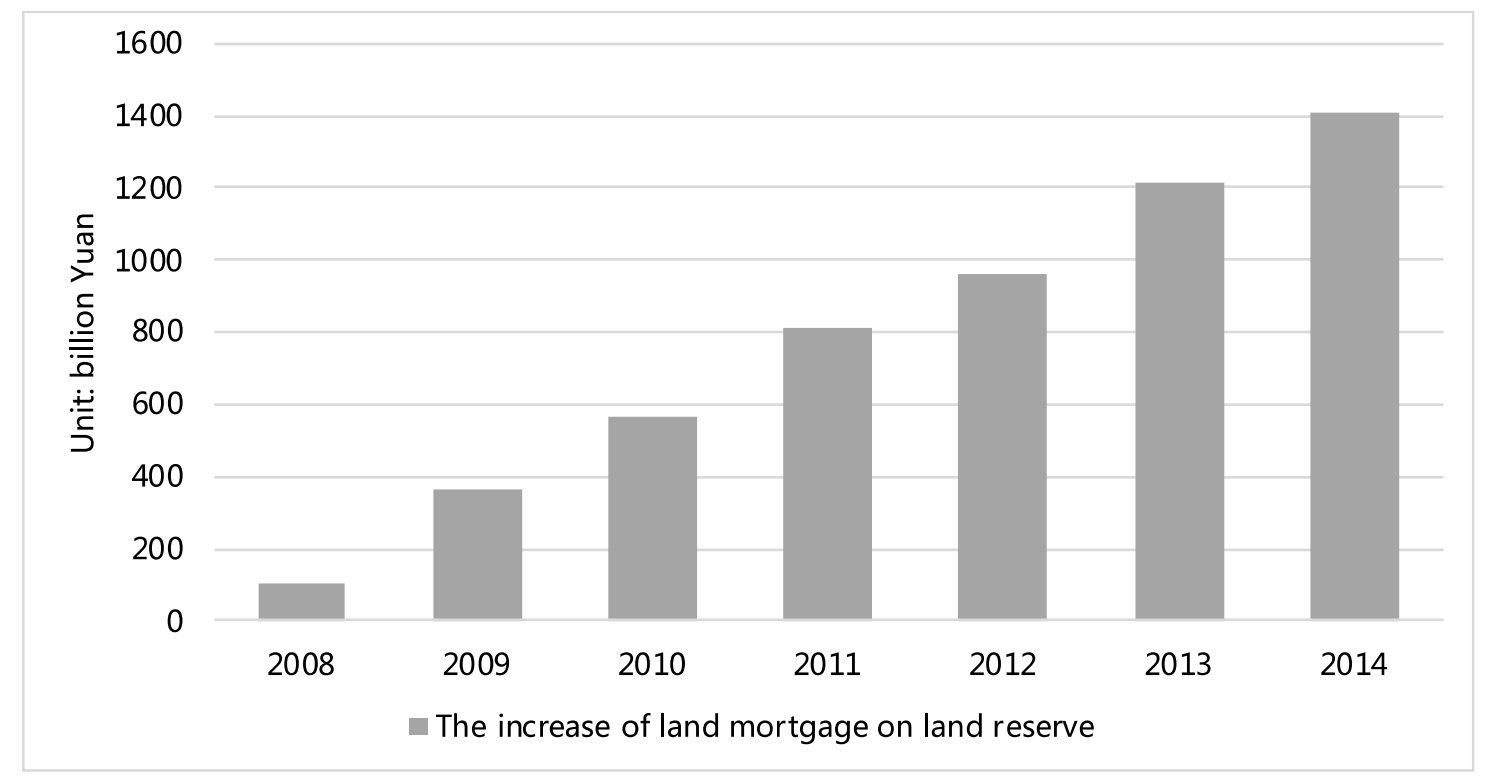

Figure 1 The increase of land mortgage based on land reserve in 84 Chinese cities (Unit: billion Yuan) (Source: Ministry of Land and Resources, 2017) 


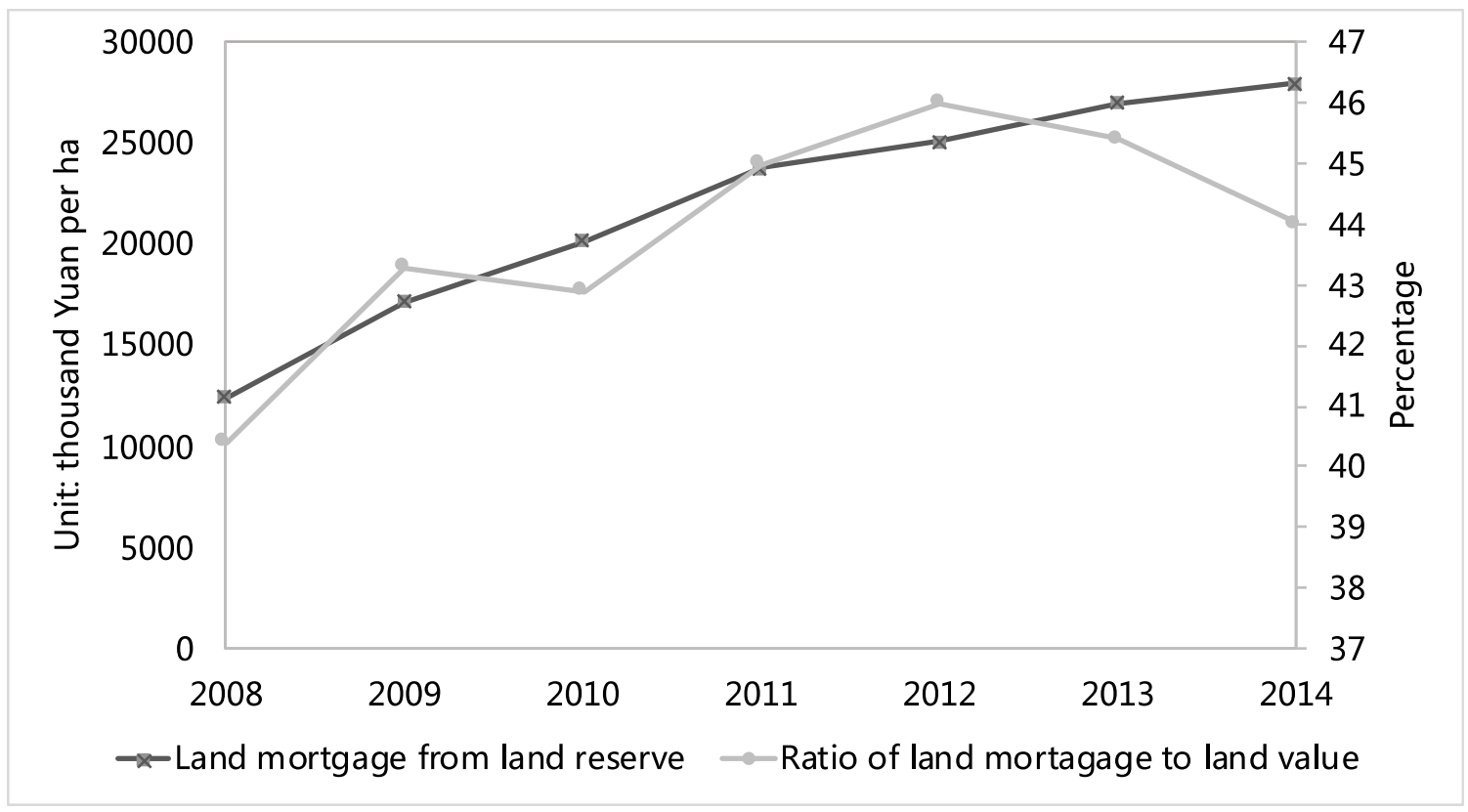

Figure 2 The land mortgage based on per hectare land reserve and the ratio of loan to value in 84 Chinese cities (Source: Ministry of Land and Resources, 2017) 


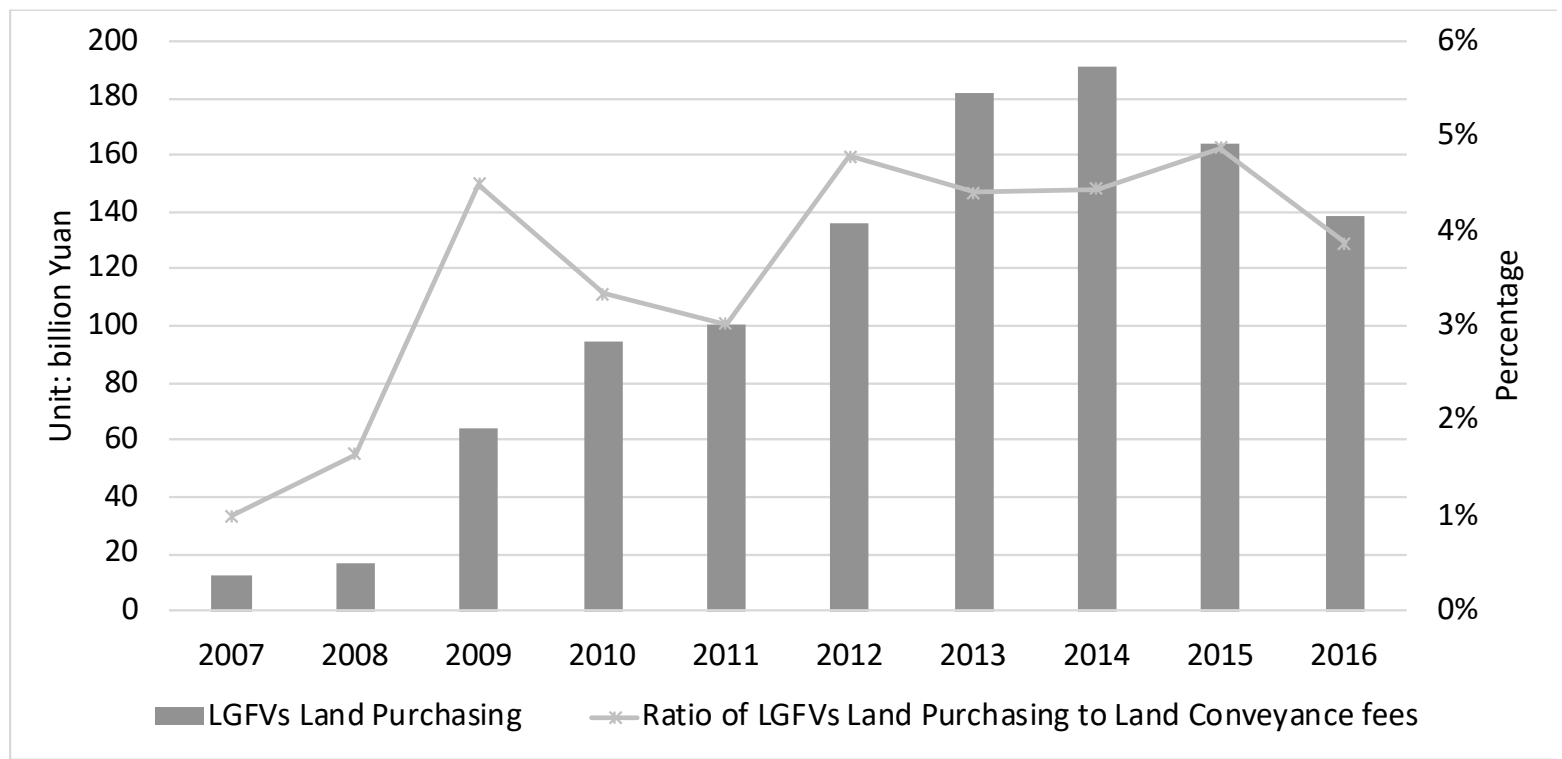

Figure 3 Land conveyance fees contributed by LGFVs (Source: WIND and China land database) 
3000

2500

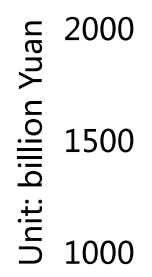

500

0

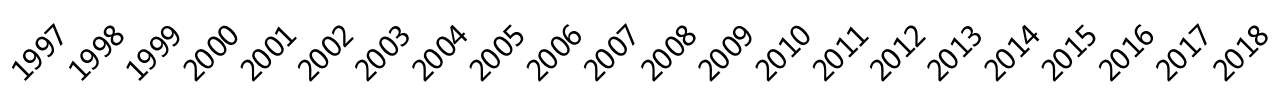

Chengtou bonds issuance

Figure 4 Chengtou bonds issued since 1997 (Source: Ang et al 2016, p. 38;

finance.sina.com.cn 15 January 2019> 


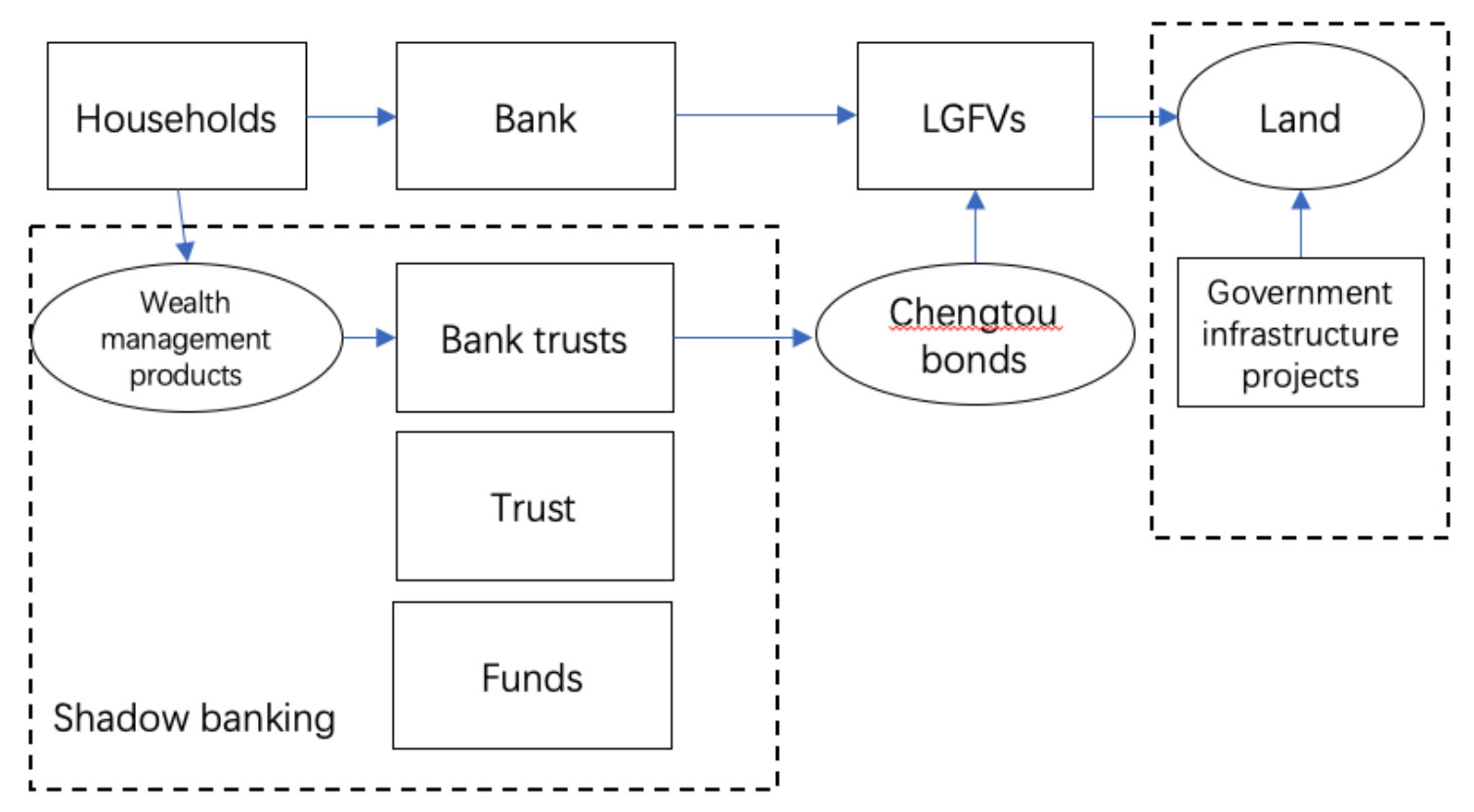

Figure 5 The links between shadow banking, wealth management products, and Chengtou bonds in the financialization of land in China 


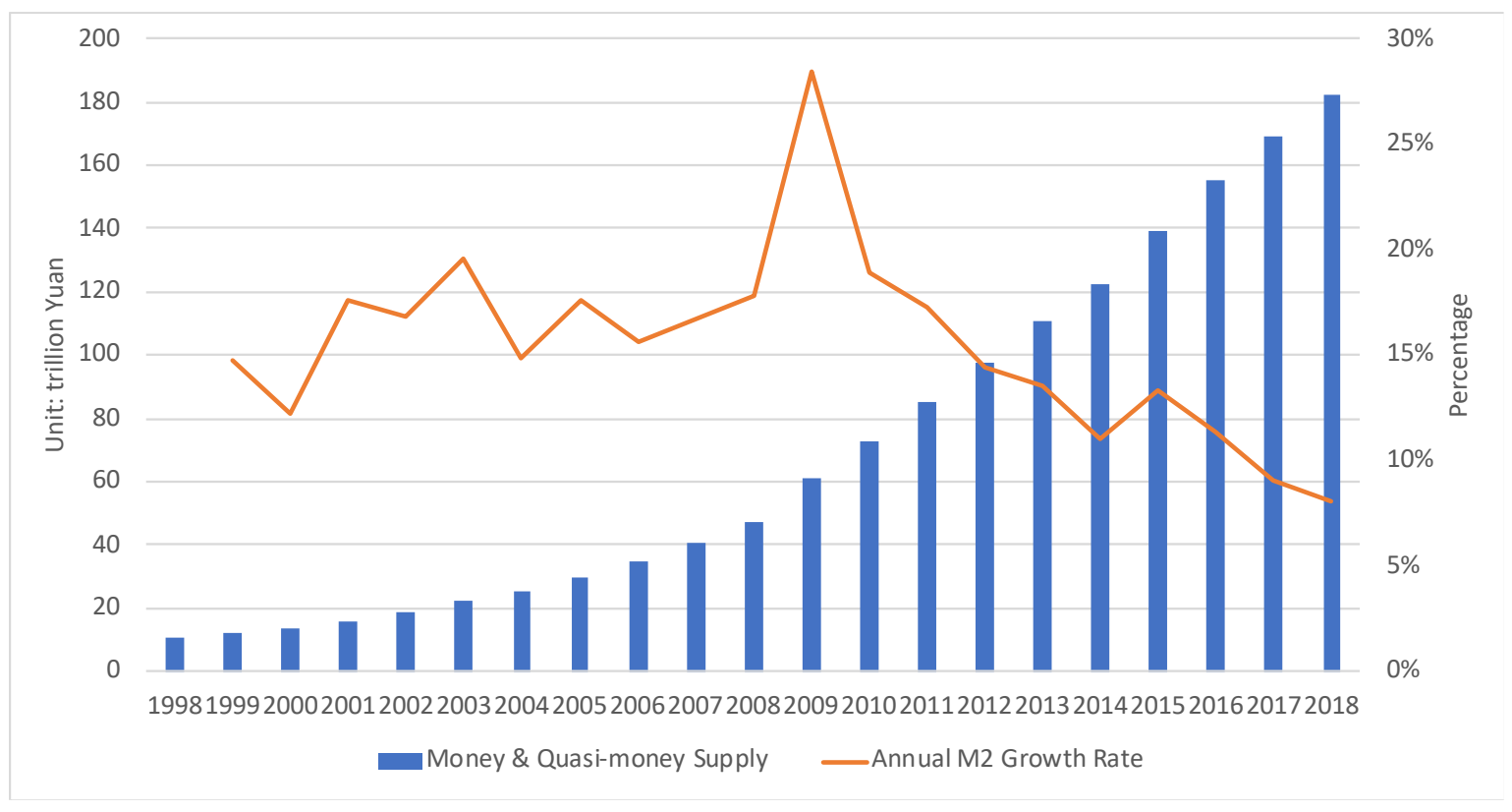

Figure 6 The increase of monetary supply (M2) in China (Source: The People's Bank of China, 2019) 


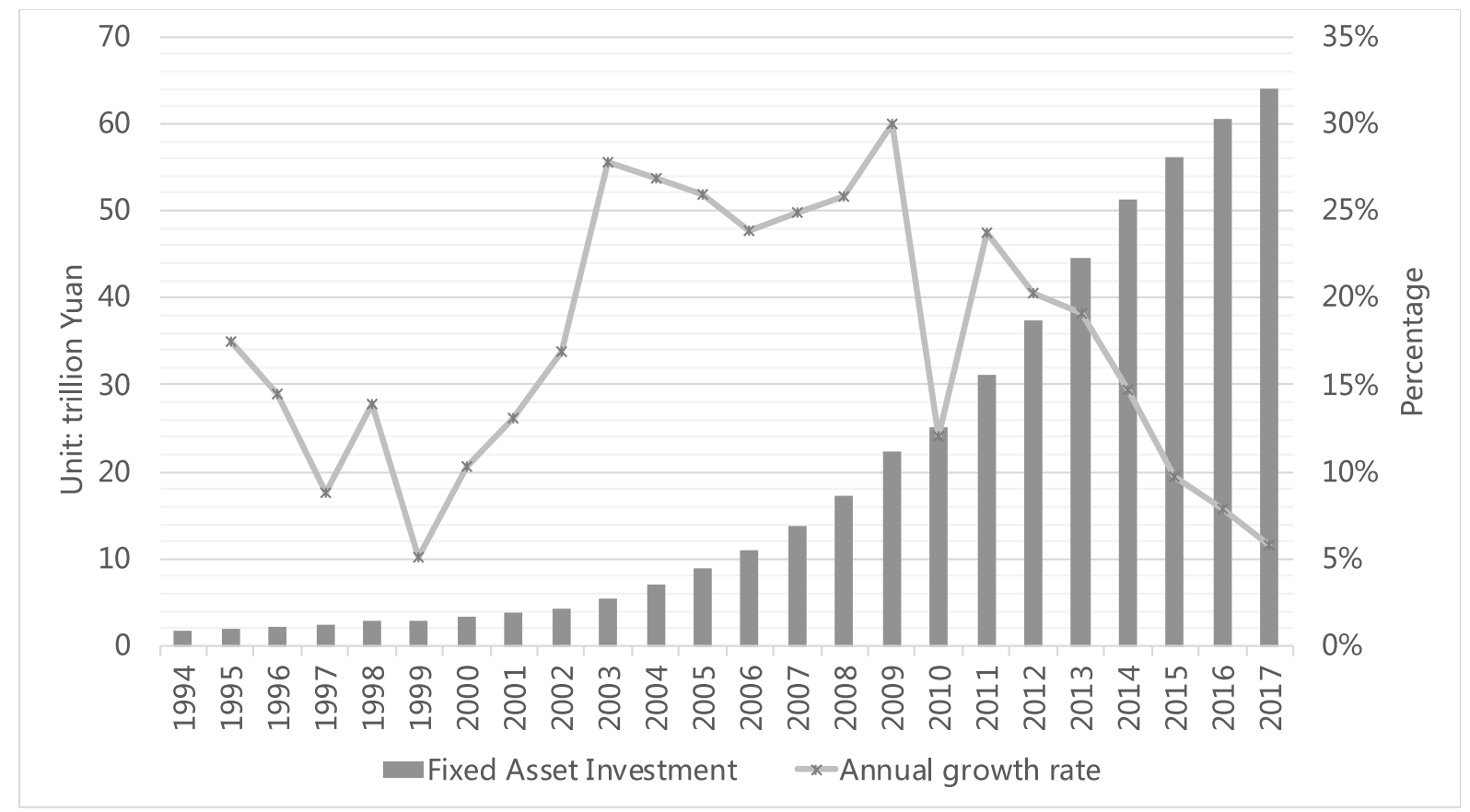

Figure 7 The increase of investment in fixed assets in China (Source: China State Statistics Bureau, 2018) 